Greener Journal of Environmental Management and Public Safety

Vol. 8(1), pp. 15-24, 2019

ISSN: 2354-2276

Copyright (C2019, the copyright of this article is retained by the author(s)

DOI Link: htto://doi.org/10.15580/GJEMPS.2019.1.020919029

http://gjournals.org/GJEMPS

\title{
Assessment of Fluoride and selected heavy metals in food chain around Fluorspar mining Plant, Kenya
}

\section{Barmao J. Kibet ${ }^{1}$, Cherutoi K. Jackson ${ }^{1}$, Mitei Y. Cheruiyot ${ }^{2}$, Were L.L. Munyendo ${ }^{1}$, Kiprop Ambrose ${ }^{1}$, Achieng' G. Oindo ${ }^{3^{*}}$}

\author{
${ }^{1}$ Department of Chemistry \& Biochemistry, Moi University, P.O. Box 3900-30100, Eldoret \\ ${ }^{2}$ Department of Chemistry \& Biochemistry, University of Eldoret, P.O. Box 1125-30100, Eldoret \\ ${ }^{3}$ Department of Chemistry, Maseno University, P.O. Box 333-40105, Maseno, Kenya
}

Article No.: 020919029

Type: Research

DOI: 10.15580/GJEMPS.2019.1.020919029

Submitted: 09/02/2019

Accepted: $14 / 02 / 2019$

Published: 28/02/2019

${ }^{\star}$ Corresponding Author

Achieng' G. Oindo

E-mail: georgeoindo@gmail.com

Keywords: heavy metals; caprine, mutton; food chain; Fluorspar mining Plant
The purpose of the research was to assess the levels of fluoride and selected heavy metals in caprine, mutton, and vegetation around the Fluorspar mining plant in Kerio Valley. Previous studies have reported contamination of water and soil by acidic factory discharges laced with hazardous heavy metals and fluoride in Kerio Valley, Kenya. However, there is no data on Fluoride and selected heavy metals in food chain around Fluorspar mining Plant. This formed the motivation behind the study to avail the data on the level of contamination. The experimental design was an entirely randomized design where mutton, caprine, and plant (leaves, grass, corn maize) samples were randomly collected from the three locations (Tumeiyo, Choff, and Kimwarer) in three replicates and Turesia which was selected as the reference or control site. Sample preparations and analyses were done according to recommended methods. Fluoride levels were 6.34 2.45 $\mathrm{mg} / \mathrm{Kg}$ and $9.58 \pm 6.03 \mathrm{mg} / \mathrm{Kg}$ in caprine and mutton, respectively. Heavy metals ranged between $0.06 \pm 0.02-0.06 \pm 0.03 \mathrm{mg} / \mathrm{Kg}$ for $\mathrm{Pb}, 0.06 \pm 0.03-0.09 \pm 0.06 \mathrm{mg} / \mathrm{Kg}$ for $\mathrm{Cd}, 3.31 \pm 1.90-3.66 \pm 2.41 \mathrm{mg} / \mathrm{Kg}$ for $\mathrm{Zn}, 0.51 \pm 0.32-0.82 \pm 0.55 \mathrm{mg} / \mathrm{Kg}$ for $\mathrm{Fe}$ and $0.44 \pm 0.28-0.54 \pm 0.33 \mathrm{mg} / \mathrm{Kg}$ for $\mathrm{Cr}$. Fluoride levels in vegetation ranged between $4.77 \pm 2.52$ and $6.27 \pm 3.40 \mathrm{mg} / \mathrm{Kg}$, while heavy metal levels ranged between $0.01 \pm 0.01-0.04 \pm 0.02 \mathrm{mg} / \mathrm{Kg}$ for $\mathrm{Pb}, 0.02 \pm 0.02-0.05 \pm 0.03 \mathrm{mg} / \mathrm{Kg}$ for $\mathrm{Cd}, 0.26 \pm 0.21$ $0.48 \pm 0.30 \mathrm{mg} / \mathrm{Kg}$ for $\mathrm{Zn}, 0.21 \pm 0.15-0.50 \pm 0.34 \mathrm{mg} / \mathrm{Kg}$ for $\mathrm{Fe}$ and $0.19 \pm 0.14-0.23 \pm 0.18$ $\mathrm{mg} / \mathrm{Kg}$ for $\mathrm{Cr}$. Zn, Fe and $\mathrm{Cr}$ levels in meat and fluoride surpassed the WHO/FAO maximum limits while $\mathrm{Pb}$ and $\mathrm{Cd}$ in all the samples were within allowable limits. Conclusively, meat recorded higher analytes concentrations compared to vegetation. The fact that the levels of key chemical analytes in the assessed samples were availed and the contamination status indicated, presented the primary significance of this research. 


\section{INTRODUCTION}

Fluorspar is the rock containing the mineral fluorite $\left(\mathrm{CaF}_{2}\right)$, a purple product used in the glazing industry, making of fiberglass, manufacturing of toothpaste, aluminium, steel, uranium fuel, refrigerants, and insulating foams. Natural fluorspar is commonly associated with other minerals such as quartz, barite, calcite, galena, siderite, celestite, chalcopyrite and phosphates [30].Calcium fluoride is mined and processed in Kerio Valley, located in Kimwarer, Keiyo South district in Kenya. The Fluorspar Mining and Processing Plant is one of the most substantial capital investments that have been made in the Kerio Valley. In the lowlands and parts of the escarpments in Kerio Valley, furrow irrigation is widely practiced where crops such as maize, beans, groundnuts, and tomatoes are grown. Also, the residents keep livestock such as cattle, sheep, and goats. The traditional system of livestock management is free ranging that involves animals being moved from one place to another in quest of water and pasture.

Despite the economic importance of mining, by generating financial wealth and prosperity, many of the activities associated with mining have adverse environmental effects. Several contaminants released through mining activities are present in the environment as exchangeable ions which can readily be moved and dispersed into the ecosystem. Elements that accumulate in biological tissues thus get converted to other chemical forms and are passed on through numerous pathways, e.g., when an animal eats contaminated plants, the contaminant moves via the blood to soft tissue, the liver, kidneys, and bones, eventually reaching all parts of the body. The final consumers in the food chain are human beings hence the likely recipients of high levels of minerals from 'contaminated' food and may accumulate high concentrations of some minerals in their tissues [31]. Most of the minerals especially heavy metals such as lead, mercury, uranium, chromium, fluoride, and arsenic are toxic. These metals affect all living organisms and have a possible toxic effect on all levels of the food chain through the contamination of land and vegetation that people and livestock use for subsistence[35].The phytotoxic impacts of heavy metal pollution are very commonly observed on crops which may be taken by animals. A high concentration of toxic elements leads to low fitness, reproduction problems and reduced immunity of animals. The consumption of food, e.g., meat and plants contaminated by toxic metals can cause depletion of the body stores of iron, Vitamin C leading to decreased immunological defenses, etc. Many studies are indicating the link between heavy metals and cancer [6]. Excess intake of fluoride through contaminated water emanating from mining industries has also been noted to contribute to fluorosis in livestock [32]. It has been established that fluoride reduces secretion of thyroid glands by affecting iodine in the body which may lead to Down's syndrome which is the abnormal condition in children resulting in the flat face, short stature, and mental retardation. Besides, excess fluoride intake causes intestinal problems like loss of appetite, nausea, vomiting, abdominal pain, intermittent diarrhea, muscular weakness and excessive thirst [24].

The contamination of agricultural land with lead, zinc, and fluoride was reported by Geeson et al. [17] in the old fluorspar mining areas of Derbyshire, UK. Contamination of water and soil by acidic factory discharges laced with hazardous heavy metals and fluoride in Kerio Valley, Kenya has also been reported in previous studies [2430]. They showed that some acidic factory effluents containing high concentrations of fluoride and heavy metals were discharged directly into river Kerio and the neighboring farms and these could have an impact on the plant-animal-human food chain. Toxicity risks can be estimated by determining the extent to which living organisms are exposed to contaminants [36]. Detection of toxicity problems can be achieved by focusing on the nutrient sources of the members of the society, i.e., food. This study, therefore, focused on sheep meat, goat meat, and plants such as maize ingested by humans around fluorspar factory. The primary aim of the study was to examine whether the local food chain is contaminated with fluoride and the selected heavy metals $(\mathrm{Pb}, \mathrm{Fe}, \mathrm{Zn}, \mathrm{Cd}$, and $\mathrm{Cr}$ ) as a result of fluorspar mining in Kerio Valley, Kenya.

\section{MATERIALS AND METHODS}

\section{Study Area and Design}

The study was carried out in Elgeiyo Marakwet County in the Kerio Valley, a place that is well known for its significant fluorite deposits. The area is defined by $0^{0}$ $19^{\prime} \mathrm{N}$ and $0^{\circ} 22^{\prime} \mathrm{N}$ latitudes and $35^{\circ} 35^{\prime} \mathrm{E}$ and $35^{\circ} 38^{\prime} \mathrm{E}$ longitudes. The Kimwarer River, a tributary of the Kerio River starts from the escarpment headland to the south and flows past the mines.

Due to fluorspar mining and processing operations, there is a high possibility of environmental contamination in this area, and this is one of the major factors that prompted the choice of the study area. The larger area comprises of rural areas (Tumeiyo, Choff sub locations, and Kimwarer center) where groundwater is the primary source of water for the animals and humans. The experimental design was a completely randomized design where mutton, caprine, and plant (leaves, grass, corn maize) samples were randomly collected from the three locations (Tumeiyo, Choff, and Kimwarer ) in three replicates and Turesia which was chosen as the reference or control site which is located about $20 \mathrm{Km}$ upstream from the factory. The control area was 
selected since the residents in the area practice free from factory pollution. range as it is done in the study area and the area is free
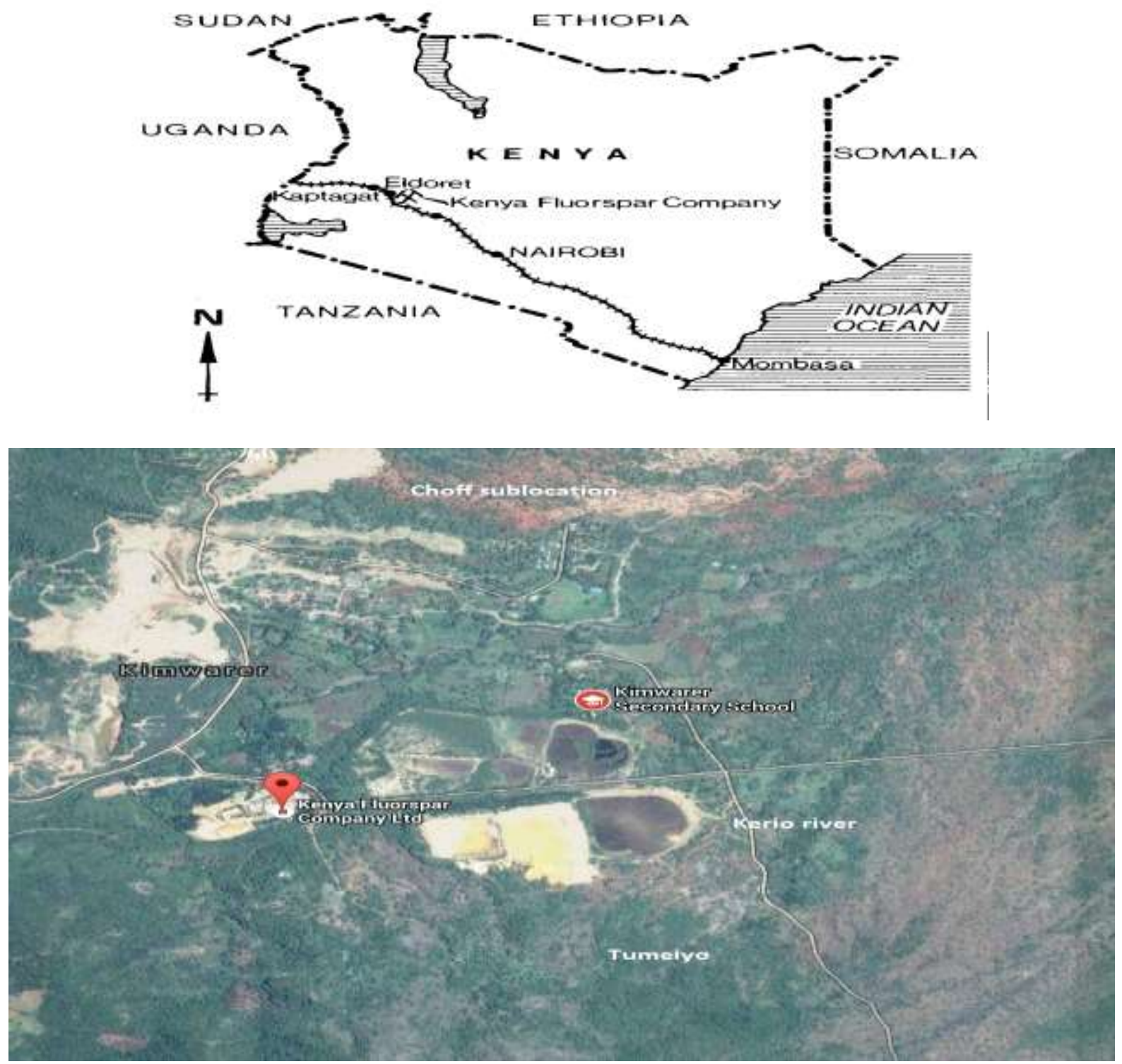

Figure 1: Map showing the location of Kenya Fluorspar Company and the sampled areas

\section{Sampling}

\section{Meat Samples}

Goat and sheep meat samples were obtained from the butcheries in the three locations (Tumeiyo, Choff, and Kimwarer) around the factory and from Turesia (the control site). Three butcheries in each of the locations within the study area were randomly selected, i.e., all the butcheries were listed in each of the locations in a different piece of paper, folded and placed in a container and consequently drawn randomly. Prerequisites for this selection were that the villagers reared goats and sheep, butchery owners slaughter animals only from the study area and that the communities consumed the butchery meat. Meat samples were obtained from the muscles and the soft tissues in which three replicate samples weighing half a kilogram each taken from each butchery. The samples were collected, accurately labeled in polyethylene bags which were then packed in the cooler boxes equipped with ice packs and transported to the Government chemistry laboratory for analysis.

\section{Plant samples}

The common plants and shrubs eaten by the goats were identified through the information given by the goats and sheep owners in the area. Species common in the area 
include Balanitacea agyptiaca, Uvariascheffleri, Ficussycomorus, Vetiver grass, Kikuyu grass and Elephant grass (Pennisetum purpurcum). Plant samples were collected from the three locations (Tumeiyo, Choff, and Kimwarer) within the study area. In each location, three sampling points were selected and one owner selected to assist in identifying plants eaten by goats and sheep. The distance between any two sampling points was approximately $1 \mathrm{Km}$, and the total sampled area was about $24 \mathrm{Km}^{2}$. The plant samples were collected by cutting the foliage of the plants. Samples of corn maize were randomly collected from three farms in each of the three locations in the study area. All samples were placed in plastic bags, labeled and taken to the Government chemistry laboratory for analysis.

\section{Calibration Standards}

Fluoride ion standards were prepared within the linear range of $0.00-10.00 \mathrm{ppm}$ using the standard $\mathrm{NaF}$ solution and standard curve obtained by plotting potential response against concentration giving $R^{2}$ value of 0.994 . The individual heavy metal standards were prepared within the linear range of $0.000-5.000 \mathrm{ppm}$, and calibration graphs of absorbance against concentration were plotted to give $R^{2}$ values ranging between 0.990-0.999.

\section{Data Analysis}

Statistical Analysis System (SAS) Version 9.2 (SAS Inc., 2002) and Microsoft Office Excel was used to analyze the generated data. Analysis of variance (ANOVA) on the ranked fluoride and selected heavy metal levels were used to evaluate whether the means were statistically similar or different from each other at the various sampling points.

\begin{tabular}{|c|c|c|c|c|c|}
\hline Parameter & Lead & Cadmium & Zinc & Iron & Chromium \\
\hline Wavelength (nm) & 248.3 & 213.9 & 279.5 & 324.7 & 217.0 \\
\hline Lamp current (mA) & 8.0 & 3.0 & 5.0 & 5.0 & 5.0 \\
\hline Band pass (nm) & 0.3 & 1.0 & 0.5 & 1.0 & 1.0 \\
\hline Burner Height (mm) & 20.0 & 22.0 & 22.0 & 24.0 & 20.0 \\
\hline $\begin{array}{l}\text { Fuel and oxidizer flow } \\
\text { rate }\left(\mathrm{cm}^{3} / \mathrm{min}\right)\end{array}$ & 5.0 & 5.0 & 5.0 & 5.0 & 5.0 \\
\hline
\end{tabular}

Table 2: WHO/FAO standards for fluoride and heavy metals in plants

\begin{tabular}{llc}
\hline Element & Sample & WHO/FAO $(\mathrm{mg} / \mathrm{Kg})$ \\
\hline \multirow{2}{*}{ Fluoride } & Leaves & 1.5 \\
& Grass & 1.5 \\
& Corn maize & 1.5 \\
\hline \multirow{2}{*}{ Lead } & Leaves & 2 \\
& Grass & 2 \\
& Corn maize & 2 \\
\hline \multirow{2}{*}{ Cadmium } & Leaves & 1 \\
& Grass & 1 \\
& Corn maize & 1 \\
\multirow{2}{*}{ Zinc } & Leaves & 60 \\
& Grass & 60 \\
& Corn maize & 60 \\
\multirow{2}{*}{ Iron } & Leaves & 48 \\
& Grass & 48 \\
& Corn maize & 48 \\
\multirow{2}{*}{ Chromium } & Leaves & 1 \\
& Grass & 1 \\
\hline
\end{tabular}


Table 3: WHO/FAO Recommended maximum permissible levels of heavy metals in meat Metals Maximum permissible level in $\mathrm{mg} / \mathrm{Kg}$

\begin{tabular}{lc}
\hline Cadmium & $0.05-0.5$ \\
Lead & 0.5 \\
Zinc & $0.3-1.0$ \\
Iron & 0.01 \\
Chromium & 0.05 \\
\hline
\end{tabular}

Source (WHO \& FAO, 2011)

\section{RESULTS AND DISCUSSION}

The mean concentrations of fluoride and heavy metals in mutton, caprine, leaves, grass, and corn maize in different sampling locations in Kenya Fluorspar mining area are presented in Tables 4,5 and 6 . Owing to a large amount of data presented in Table 4, means of means have been generated and rearranged in Tables 5 and 6 from which significant discussions have been made in this paper.

Table 4: Mean concentrations (mean $\pm S D$ ) of fluoride and selected heavy metals in mutton, caprine, leaves, grass, and corn maize from different sampling locations in Kenya Fluorspar mining area

\begin{tabular}{|c|c|c|c|c|c|c|c|}
\hline \multicolumn{8}{|c|}{ Chemical Parameters } \\
\hline Location & Sample Identity & $\mathrm{F}$ & $\mathrm{Pb}$ & $\mathrm{Cd}$ & $\mathrm{Zn}$ & $\mathrm{Fe}$ & $\mathrm{Cr}$ \\
\hline \multirow{5}{*}{ Tumeiyo } & Caprine & $5.70 \pm 0.10$ & $0.07 \pm 0.03$ & $0.16 \pm 0.04$ & $5.09 \pm 1.05$ & $0.86 \pm 0.11$ & $0.79 \pm 0.04$ \\
\hline & Mutton & $7.92 \pm 0.02$ & $0.09 \pm 0.02$ & $0.09 \pm 0.03$ & $6.52 \pm 1.77$ & $1.50 \pm 0.26$ & $0.92 \pm 0.04$ \\
\hline & Leaves & $4.82 \pm 0.92$ & $0.02 \pm 0.01$ & $0.05 \pm 0.02$ & $0.50 \pm 0.26$ & $0.39 \pm 0.02$ & $0.40 \pm 0.05$ \\
\hline & Grass & $6.03 \pm 0.10$ & $0.01 \pm 0.01$ & $0.07 \pm 0.02$ & $0.40 \pm 0.02$ & $0.59 \pm 0.06$ & $0.41 \pm 0.04$ \\
\hline & Corn maize & $6.22 \pm 0.11$ & $0.03 \pm 0.02$ & $0.09 \pm 0.02$ & $0.79 \pm 0.05$ & $0.97 \pm 0.10$ & $0.50 \pm 0.04$ \\
\hline \multirow{5}{*}{ Choff } & Caprine & $6.65 \pm 0.05$ & $0.06 \pm 0.01$ & $0.07 \pm 0.04$ & $3.95 \pm 0.24$ & $0.54 \pm 0.05$ & $0.43 \pm 0.04$ \\
\hline & Mutton & $14.90 \pm 1.02$ & $0.07 \pm 0.02$ & $0.05 \pm 0.02$ & $3.66 \pm 0.18$ & $0.80 \pm 0.26$ & $0.56 \pm 0.03$ \\
\hline & Leaves & $6.80 \pm 0.27$ & $0.01 \pm 0.01$ & $0.01 \pm 0.01$ & $0.22 \pm 0.05$ & $0.25 \pm 0.06$ & $0.18 \pm 0.03$ \\
\hline & Grass & $8.42 \pm 0.84$ & $0.01 \pm 0.01$ & $0.01 \pm 0.01$ & $0.44 \pm 0.05$ & $0.36 \pm 0.04$ & $0.18 \pm 0.03$ \\
\hline & Corn maize & $8.89 \pm 0.58$ & $0.06 \pm 0.02$ & $0.03 \pm 0.02$ & $0.48 \pm 0.05$ & $0.50 \pm 0.04$ & $0.21 \pm 0.04$ \\
\hline \multirow{5}{*}{ Kimwarer } & Caprine & $6.66 \pm 0.03$ & $0.06 \pm 0.03$ & $0.09 \pm 0.01$ & $3.78 \pm 0.14$ & $0.62 \pm 0.05$ & $0.48 \pm 0.06$ \\
\hline & Mutton & $14.62 \pm 0.45$ & $0.06 \pm 0.02$ & $0.07 \pm 0.01$ & $4.08 \pm 0.07$ & $0.89 \pm 0.08$ & $0.62 \pm 0.03$ \\
\hline & Leaves & $6.60 \pm 0.31$ & $0.01 \pm 0.01$ & $0.02 \pm 0.02$ & $0.28 \pm 0.03$ & $0.19 \pm 0.06$ & $0.09 \pm 0.05$ \\
\hline & Grass & $8.71 \pm 0.45$ & $0.01 \pm 0.01$ & $0.04 \pm 0.01$ & $0.60 \pm 0.10$ & $0.39 \pm 0.03$ & $0.12 \pm 0.03$ \\
\hline & Corn maize & $8.98 \pm 0.50$ & $0.03 \pm 0.02$ & $0.06 \pm 0.02$ & $0.58 \pm 0.03$ & $0.47 \pm 0.05$ & $0.18 \pm 0.04$ \\
\hline \multirow{5}{*}{ Turesia } & Caprine & $1.00 \pm 0.01$ & $0.03 \pm 0.02$ & $0.02 \pm 0.01$ & $0.40 \pm 0.30$ & $0.03 \pm 0.01$ & $0.05 \pm 0.02$ \\
\hline & Mutton & $0.87 \pm 0.03$ & $0.02 \pm 0.02$ & $0.02 \pm 0.01$ & $0.38 \pm 0.09$ & $0.09 \pm 0.03$ & $0.04 \pm 0.01$ \\
\hline & Leaves & $0.87 \pm 0.03$ & ND & ND & $0.04 \pm 0.03$ & $0.01 \pm 0.01$ & $0.09 \pm 0.05$ \\
\hline & Grass & $1.00 \pm 0.01$ & ND & ND & ND & $0.01 \pm 0.00$ & $0.05 \pm 0.02$ \\
\hline & Corn maize & $1.00 \pm 0.02$ & $0.01 \pm 0.01$ & $0.02 \pm 0.01$ & $0.03 \pm 0.02$ & $0.05 \pm 0.02$ & $0.05 \pm 0.04$ \\
\hline
\end{tabular}

ND-Not Detected; Turesia- Contol location; the units are given in $\mathrm{mg} / \mathrm{Kg}$ 
Table 5: Overall mean concentrations (mean \pm SD) variations of fluoride and selected heavy metals in mutton, caprine, leaves, grass, and corn maize in Kenya Fluorspar mining area due to location

\begin{tabular}{ccccccc}
\hline \multicolumn{7}{c}{ Chemical Parameters } \\
Location & $\mathrm{F}$ & $\mathrm{Pb}$ & $\mathrm{Cd}$ & $\mathrm{Zn}$ & $\mathrm{Fe}$ & $\mathrm{Cr}$ \\
\hline Tumeiyo & $6.14 \pm 1.10^{\mathrm{b}}$ & $0.05 \pm 0.04^{\mathrm{a}}$ & $0.09 \pm 0.04^{\mathrm{a}}$ & $2.66 \pm 2.81^{\mathrm{a}}$ & $0.86 \pm 0.41^{\mathrm{a}}$ & $0.60 \pm 0.22^{\mathrm{a}}$ \\
Choff & $9.13 \pm 3.17^{\mathrm{a}}$ & $0.04 \pm 0.03^{\mathrm{a}}$ & $0.04 \pm 0.03^{\mathrm{c}}$ & $1.75 \pm 1.75^{\mathrm{b}}$ & $0.49 \pm 0.22^{\mathrm{b}}$ & $0.31 \pm 0.17^{\mathrm{b}}$ \\
Kimwarer & $9.11 \pm 3.05^{\mathrm{a}}$ & $0.04 \pm 0.02^{\mathrm{A}}$ & $0.06 \pm 0.03^{\mathrm{b}}$ & $1.86 \pm 1.76^{\mathrm{b}}$ & $0.51 \pm 0.25^{\mathrm{b}}$ & $0.30 \pm 0.22^{\mathrm{b}}$ \\
Turesia & $0.95 \pm 0.07^{\mathrm{c}}$ & $0.01 \pm 0.02^{\mathrm{b}}$ & $0.01 \pm 0.01^{\mathrm{d}}$ & $0.17 \pm 0.22^{\mathrm{c}}$ & $0.04 \pm 0.03^{\mathrm{c}}$ & $0.06 \pm 0.03^{\mathrm{c}}$ \\
LSD p $\leq 0.05$ & 0.32 & 0.01 & 0.01 & 0.35 & 0.07 & 0.03 \\
\hline \multicolumn{5}{l}{ Means with distinct letters are statistically different at $\mathrm{P} \leq 0.05 ;$ the units are given in $\mathrm{mg} / \mathrm{Kg}$}
\end{tabular}

Table 6: Overall mean concentrations (mean \pm SD) of fluoride and selected heavy metals in mutton, caprine, leaves, grass and corn maize in Kenya Fluorspar mining area

\begin{tabular}{ccccccc} 
& \multicolumn{5}{c}{ Chemical Parameters } \\
Sample & $\mathrm{F}$ & $\mathrm{Pb}$ & $\mathrm{Cd}$ & $\mathrm{Zn}$ & $\mathrm{Fe}$ & $\mathrm{Cr}$ \\
\hline Caprine & $6.34 \pm 2.45^{\mathrm{c}}$ & $0.06 \pm 0.02^{\mathrm{a}}$ & $0.09 \pm 0.06^{\mathrm{a}}$ & $3.31 \pm 1.90^{\mathrm{a}}$ & $0.51 \pm 0.32^{\mathrm{b}}$ & $0.44 \pm 0.28^{\mathrm{b}}$ \\
Mutton & $9.58 \pm 6.03^{\mathrm{c}}$ & $0.06 \pm 0.03^{\mathrm{a}}$ & $0.06 \pm 0.03^{\mathrm{b}}$ & $3.66 \pm 2.41^{\mathrm{a}}$ & $0.82 \pm 0.55^{\mathrm{a}}$ & $0.54 \pm 0.33^{\mathrm{a}}$ \\
Leaves & $4.77 \pm 2.52^{\mathrm{c}}$ & $0.01 \pm 0.01^{\mathrm{c}}$ & $0.02 \pm 0.02^{\mathrm{c}}$ & $0.26 \pm 0.21^{\mathrm{b}}$ & $0.21 \pm 0.15^{\mathrm{d}}$ & $0.19 \pm 0.14^{\mathrm{d}}$ \\
Grass & $6.04 \pm 3.25^{\mathrm{b}}$ & $0.01 \pm 0.01^{\mathrm{c}}$ & $0.03 \pm 0.03^{\mathrm{c}}$ & $0.36 \pm 0.24^{\mathrm{b}}$ & $0.34 \pm 0.22^{\mathrm{c}}$ & $0.19 \pm 0.14^{\mathrm{d}}$ \\
Corn maize & $6.27 \pm 3.40^{\mathrm{b}}$ & $0.04 \pm 0.02^{\mathrm{b}}$ & $0.05 \pm 0.03^{\mathrm{b}}$ & $0.48 \pm 0.30^{\mathrm{b}}$ & $0.50 \pm 0.34^{\mathrm{b}}$ & $0.23 \pm 0.18^{\mathrm{c}}$ \\
CV\% & 6.88 & 41.73 & 39.08 & 29.56 & 20.51 & 11.86 \\
LSD p $\leq 0.05$ & 0.36 & 0.01 & 0.02 & 0.39 & 0.12 & 0.02 \\
\hline
\end{tabular}

Means with distinct letters are statistically different at $\mathrm{P} \leq 0.05$; the units are given in $\mathrm{mg} / \mathrm{Kg}$

As shown in Table 5 above, the overall mean Fluoride levels in animals (mutton and caprine) were $9.58 \pm 6.03$ and $6.34 \pm 2.45 \mathrm{mg} / \mathrm{Kg}$ respectively, while the concentrations for the selected heavy metals ranged between $0.06 \pm 0.02$ and $3.66 \pm 2.41 \mathrm{mg} / \mathrm{Kg}$. Fluoride levels in plants (leaves, grass and corn maize) ranged between $4.77 \pm 2.52$ and $6.27 \pm 3.40 \mathrm{mg} / \mathrm{Kg}$ while the concentrations for the selected heavy metals ranged between $0.01 \pm 0.01$ and $0.48 \pm 0.30 \mathrm{mg} / \mathrm{Kg}$. Generally, animal samples had higher concentrations of the studied elements than plant samples. This is likely because bioaccumulation in animals is higher than in plants and the ability of animals to move to different regions while grazing on grass, leaves, and drinking of fluoridated water. Nguta et al. [25] reported high levels of fluoride and heavy metals in water and soil around the Kenya fluorspar factory and therefore, the presence of these elements might have led to the bioaccumulation in animals and plants. This is consistent with the report by Baars et al. [9]. These results mean that there is a potential risk that could be looming on the health of the animals as well as the human beings who consume meat.

Fluoride and heavy metals $(\mathrm{Fe}, \mathrm{Cr}, \mathrm{Zn}, \mathrm{Cd}$, and $\mathrm{Pb}$ ) concentrations in plants showed that the elemental contents differed among plant samples. This observation can be attributed to their different capacities for Fluoride and metal uptake. On the other hand, higher concentrations of all the elements were found in corn maize compared to the other plants (leaves and grass). 
The finding is in harmony with previous studies [6] where it was attested that maize could be used as a phytoremediation tool owing to its better ability to bioaccumulate heavy metals than other plants. The variations of various heavy metal concentrations in different plant species also concur with the report of the work on seasonal fluctuations in heavy metal concentrations in soil and some selected crops[11]. In this study, elemental concentration in plant species followed the order $\mathrm{F}>\mathrm{Zn}>\mathrm{Fe}>\mathrm{Cr}>\mathrm{Cd}>\mathrm{Pb}$. The pattern is analogous to the one observed in the animal samples, although the concentrations were higher in animal samples than in all the others, a fact that can be ascribed to ingestion of contaminants which ultimately causes deposition of these chemical residues in meat [45]. It can be deduced that animals and human beings involved in the food chain could get exposed to health risks.

\section{Fluoride levels in animal and plant samples}

In the present study, the high mean concentration of fluoride ion was recorded in sheep meat $(9.58 \pm 6.03 \mathrm{mg} / \mathrm{Kg})$ and goat meat showed a mean level of $6.34 \pm 2.45 \mathrm{mg} / \mathrm{Kg}$. The lowest concentration $(4.77 \pm 2.52 \mathrm{mg} / \mathrm{Kg})$ was recorded in leaves. Intake of fluoride from grass and leaves led to high fluoride in sheep and goats in the region. The current results were slightly higher than those reported by Kabata and Bendias [20] who found fluoride concentration in goat meat to range from 0.5 to $5 \mathrm{mg} / \mathrm{Kg}$. Significantly $p \leq 0.05$ higher mean concentrations were observed in animals in this study area in comparison to plants, i.e., leaves, grass, and corn maize. Goats and sheep meat samples registered higher concentration of fluoride most probably because of bioaccumulation of the element and also their ability to graze on different environments which leads to picking of the contaminant from different sources such as soil, water, grass, and leaves. Other studies have confirmed that inorganic fluorides tend to accumulate preferentially in the skeletal and dental hard tissues of vertebrates, exoskeletons of invertebrates and cell walls of plants [21-34]. Moreover, the study showed that Fluoride concentration was higher in sheep meat than goat meat probably because sheep usually graze on grasses which are believed to have high contaminants while the goats browse on leaves. It has been shown that parts of the plant closer to the soil accumulate the highest amount of soil as a result of rain drop splash [39]. Therefore, animals grazing on short plants on fluoride contaminated soils probably ended up ingesting more fluoride in this manner than did animals grazing on tall plants. Furthermore, differences between animal species concerning magnesium content in erythrocytes and plasma have been reported [39]. Sheep ordinarily have low levels of this element in red blood cells and plasma, consequently, are more susceptible to fluoride than other mammals [39]. Leaves had the lowest concentration of fluoride of all the plant samples studied. This observation can be supported by the fact that leaves are located high above the ground, therefore, might not be predisposed to contamination by rain splash except through absorption from the roots. Elloumi et al. [15] showed that 5 to $10 \%$ of the absorbed fluoride is transported to the leaves. The total fluoride content of maize grain was significantly higher than all the plant samples, i.e., leaves and grass. This could be attributed to its sensitivity to fluoride compared to other plants [3]. In the present study, fluoride levels in all the samples studied surpassed the WHO [40] permissible limit of $1.5 \mathrm{mg} / \mathrm{Kg}$. This can be ascribed to the presence of high fluoride levels in soils and waters around the study area in which fluoride mining and processing are the predominant operations. These findings clearly show the possible associated risks and safety of organisms within the food chain depending on the quantified concentrations of chemicals assayed.

\section{Lead concentrations in plant and animal samples}

The lead concentration was observed in mutton, caprine, leaves, grass and corn maize. Sheep-meat showed the highest concentration of $0.06 \pm 0.02 \mathrm{mg} / \mathrm{Kg}$ while goat meat had a concentration of $0.06 \pm 0.03 \mathrm{mg} / \mathrm{Kg}$ and corn maize showed the concentration of $0.04 \pm 0.02 \mathrm{mg} / \mathrm{Kg}$. The concentrations of lead in grass and leaves were the lowest as shown in Tables 4, 5 and 6. Similar results were obtained by Akoto et al. [4] who studied lead and other heavy metal concentrations in liver, kidney, lungs, brain, heart, and intestine of goat and sheep in a gold mining town in Ghana. Significantly higher amounts of lead were found in organs of sheep and goat reared in Kasuwan Shanu market in Nigeria [5]. The concentration of lead was the lowest in all the plants $(0.01 \pm 0.01 \mathrm{mg} / \mathrm{Kg}$ in grass and leaves and $0.04 \pm 0.02 \mathrm{mg} / \mathrm{Kg}$ in corn maize) compared to other heavy metals owing to the low concentration of the element in the soil. Also, deposited lead $(\mathrm{Pb})$ is strongly retained by most soils, resulting in lower plant concentrations compared to more bioaccessible metals such as cadmium and nickel [23]. Because of the usually low soil-to-root uptake, the above-ground plant parts are likely to be contaminated by airborne deposition of lead-containing dust or aerosols onto the plant surface [22]. Other soil factors such as soil $\mathrm{pH}$, soil nutrients and electrical conductivity determine lead mobility in the soil to plants [26]. The concentration of lead among the plant species differed in this study showing that plant species differ in their ability to accumulate heavy metals. This is consistent with previous observations by other researchers [26-37]. The results of the study showed that lead concentrations in all the samples were lower than the permissible limit in the meat of $0.5 \mathrm{mg} / \mathrm{Kg}$ [16] and $2 \mathrm{mg} / \mathrm{Kg}$ in foods and vegetables [28]. The significance of this observation is that there is no health risk involved related to lead in case of consumption. 


\section{Cadmium levels in the samples}

The Cd concentration as observed in mutton, caprine and corn maize has been summarized in Tables 4, 5 and 6 . The highest $\mathrm{Cd}$ concentration was found in goat meat $(0.09 \pm 0.06 \mathrm{mg} / \mathrm{Kg})$ and sheep meat had the concentration of $0.06 \pm 0.03 \mathrm{mg} / \mathrm{Kg}$. Aranha et al. [7] and Roger et al. [33] disclosed the cadmium levels in the livers and kidneys of cattle of Poland and found the cadmium concentration beyond the action level.

The level of cadmium concentration in plants was lower compared to goat meat and sheep meat. Leaves showed the lowest concentration than grass and corn. This can be explained by the fact that grass and corn maize are better accumulators of heavy metals compared to leaves. Vasiliki [39] showed in her study that grass was the best accumulator of cadmium, copper, iron, manganese, and zinc. Aliyu [6] examined maize and reported that it could be applied inphytoremediation of heavy metals. This indicated the remarkable ability of maize to absorb and accumulate high concentration of these metals from soil. Cadmium is usually dispersed in a natural environment through human activities as well as natural rock mineralization process thus plants can easily absorb cadmium from soil and transport it into shoot system compared to lead. The results of the studied samples were within the permissible limit. The allowable limit for cadmium in the liver has been reported as $0.5 \mathrm{mg} / \mathrm{Kg}[16]$ and maximum permissible level in plants is $2.4 \mathrm{mg} / \mathrm{Kg}$ [28]. Therefore, there is no health risk exposed in case of consumption of such food source in relation to cadmium.

\section{The concentration of Zinc in plants and animals samples}

The zinc concentrations in all the study samples are shown in Tables 4, 5 and 6 . The highest zinc concentration $(3.66 \pm 2.41 \mathrm{mg} / \mathrm{Kg})$ was found in the mutton and lowest concentration $(0.26 \pm 0.21 \mathrm{mg} / \mathrm{Kg})$ in the leaves. From the results, it is shown that the concentrations of zinc in meat samples (mutton and caprine) were above the permissible limit (0.3-1.0 $\mathrm{mg} / \mathrm{Kg}$ ) set by WHO and FAO [17]. Zinc and copper intoxication by industrial emission in the livers, kidneys, spleen, musculature, ovaries, and uterus of some experimental sheep have been reported [19]. The study showed that the highest concentration of zinc in the experimental animals that died of zinc intoxication was in the liver and kidneys. The high concentration of zinc may be attributed to the presence of zinc in soils; consequently, the grass and leaves eaten by goats and sheep contained zinc element. Perhaps, this is one of the reasons for the high level of zinc in meat. All the plant samples had low levels of zinc compared to the normal values of about $100 \mathrm{mg} / \mathrm{Kg}$ set by $\mathrm{WHO}$ and FAO [16]. This may be due to the relatively low concentration of zinc in the soil. Zinc pollution arises mainly from atmospheric deposition and could also be derived from vehicular traffic [12]. Zinc levels can be enhanced in automobile exhausts which may be elevated near road ways due to wearing out of tyres. The concentrations of zinc established in the study point out the safety of the food source; hence there are no health risks anchored.

\section{Iron concentration in plant and animals in the area}

Iron concentration in all the samples studied (mutton, caprine, grass, leaves and corn maize) are summarized in Tables 4, 5 and 6 . The highest concentration $(0.82 \pm 0.55 \mathrm{mg} / \mathrm{Kg})$ was found in sheep meat while the lowest $(0.21 \pm 0.15 \mathrm{mg} / \mathrm{Kg})$ was in leaves. The permissible limit of iron in food is $30-150 \mathrm{mg} / \mathrm{Kg}$ [14]. A study in the Kerio Valley revealed the presence of high levels of iron in Kerio River and its environments which had $0.883 \mathrm{mg} / \mathrm{Kg}$ of iron, which is about three times the World Health Organization (WHO) recommended value of $0.3 \mathrm{mg} / \mathrm{Kg}$ [16]. The presence of this element could have led to the accumulation of plants and animal tissues in the area. The iron content in the meat samples reported in this study is above the WHO permissible levels. The maximum permissible level of iron in meat is $0.01 \mathrm{mg} / \mathrm{Kg}$ [16]. The meaning of the results is that the food source could be a potential iron-related health risk.

\section{Chromium concentration in plants and animals in the study area}

The $\mathrm{Cr}$ concentration in mutton, caprine, grass, leaves and corn maize is summarized in Tables 4,5 and 6 . The highest $\mathrm{Cr}$ concentration $(0.54 \pm 0.33 \mathrm{mg} / \mathrm{Kg})$ was found in the sheep meat and the lowest $(0.19 \pm 0.14 \mathrm{mg} / \mathrm{Kg})$ in leaves. The permissible limit for $\mathrm{Cr}$ in food is about 0.5 $\mathrm{mg} / \mathrm{Kg}$ [14]. It was found that the concentration of $\mathrm{Cr}$ in the sheep meat exceeded the permissible limit. This could be attributed to the presence of the element in the soil [25]. Sheep mostly graze on grasses which are more bio-accumulators than leaves [39]. $\mathrm{Cr}$ is an essential element in helping the body to use sugar, protein and fat, but it is carcinogenic for organisms thus excessive amounts may cause adverse health effects [8]. The chromium contents in all the plant samples were within the normal range of $0.1-0.5 \mathrm{mg} / \mathrm{Kg}$ [10]. The concentration of chromium in all the plant's samples ranged from $0.19 \pm 0.14$ to $0.23 \pm 0.18 \mathrm{mg} / \mathrm{Kg}$ which is within the normal level attributable to the low uptake of the metal by plants. Soils contaminated with chromium generally from sewage sludge, tannery waste, native inorganic chromium in mine waste are mainly present as $\mathrm{Cr}$ (III). Its concentrations in goat meat were within the permissible limit, and this could be ascribed to the fact that goats mostly graze on tree leaves which have a low concentration of the element. The results have aided in availing the necessary information to consumers concerning the risk status of these food sources. 


\section{Assessment of the levels of analyzed chemical parameters based on sampling locations}

The results confirm that Choff and Kimwarer recorded levels of Fluoride and heavy metals that were numerically at par but demonstrated significant differences $(P \leq 0.05)$ for cadmium levels (Table 5). On the other hand, Tumeiyo recorded significantly the highest levels of the chemical parameters tested in this study, while the control location (Turesia) registered the least as was expected since it is likely to be free from contamination. A similar observation on the significant difference in elemental concentration based on sampling location was documented by Achieng et al. [1] for the lead on soil samples. These findings clearly show that fluorides and heavy metals contamination within an area of study is subject to a relative position between the source of the contaminants and the area.

\section{CONCLUSIONS}

All the samples studied tested positive to fluoride and selected heavy metals ( $\mathrm{Fe}, \mathrm{Cr}, \mathrm{Zn}, \mathrm{Cd}$, and $\mathrm{Pb}$ ). Sheep and goat meat registered higher concentrations of the target analytes which ranged from $0.06 \pm 0.02$ to $9.58 \pm 6.03 \mathrm{mg} / \mathrm{Kg}$ compared to plants (corn maize, leaves, and grass) that contained much lower concentrations ranging from $0.01 \pm 0.01$ to $4.77 \pm 2.52$ $\mathrm{mg} / \mathrm{Kg}$. The concentration of fluoride in all the samples (caprine, mutton, corn maize, grass, and leaves) exceeded WHO/FAO permissible limits. Statistical analysis showed that there were significant variations in the levels of the analyte in these samples and sampling locations. The high levels of fluoride in the studied samples could explain the symptoms of fluorosis which were observed in most animals' and people's teeth inhabiting the study area. The direct consumption of the leaves, grass, and water by animals from these areas may result in accumulation of high quantities of fluoride and heavy metals in their tissues as shown by the findings of the current study. The study recommends that wastewater emanating from the Fluorspar mining plant in Kerio Valley should be well treated and the pollutants quantified to reduce environmental contamination. Furthermore, more research needs to be extended to other areas within the mining plant which have a hydrological connection.

\section{ACKNOWLEDGMENT}

The authors wish to acknowledge the support of Government Chemist's laboratory, Nairobi, for some of the analytical work.

\section{REFERENCES}

1. Achieng, G.O., Ongeri, D.M.K. and Omwoyo, W.N. (2013). Impact of anthropogenic activities on copper and lead levels in Kisumu city soils. Sky Journal of Soil Science and Environmental Management, 2(5):47-52.

2. Adriano, D. C. \& Doner, H. E. (1982). Bromine, Chlorine and Fluorine. In Methods of Soil Analysis. American Society of Agronomy. Madison, WI; pp. 44983.

3. Ahmad, N., Ahmad, S., Zia, A., Shahid, M., Shah, H., Ahmad, M. and Ullah, S. (2014). Hydrogen fluoride effects on local mung bean and maize cereal crops from Peri-urban brick kilns in South Asia. Research report Fluoride, 47 (4): 315-319.

4. Akoto, O., Bortey-Sam, N., Nakayama, S. M., Ikenaka, Y., Baidoo, E., Yohannes, Y. B., Mizukawa, H. and Ishizuka, M. (2014). Distribution of Heavy Metals in Organs of Sheep and Goat Reared in Obuasi: A Gold Mining Town in Ghana. International Journal of Environmental Science of Toxicology,2 (2):81-89; P.84-86.

5. Akan, J. C., Abdulrahman, F. I., Sodipo, O. A \& Chiroma, Y. A. (2010). Distribution of Heavy Metals in the Liver, Kidney and Meat of Beef, Mutton, Caprine and Chicken from Kasuwan Shanu Market in Maiduguri Metropolis, Borno State, Nigeria. Research Journal of Applied Sciences, Engineering and Technology, 2 (8): 743-748.

6. Aliyu, H. G. and Adamu, H. M. (2014). The potential of maize as phytoremediation tool of heavy metals. European science journal,6 (10): 32-33

7. Aranha, K., (1994). Environmental Chemistry. 3rd Edn., New Age International Ltd. Publisher, New Delhi, pp: 213-219.

8. ATSDR (1999). Toxicological Profile of Cadmium. Agency for Toxic Substances and Drug Registry, US Department of Health and Human Services, Atlanta, GA.

9. Baars, A. J., van Beek, H., Spierenburg, T. J., de Graf, G. J., Beeftink, W. G., Boom, J. andPekelder, J. J. (1987). Fluoride pollution in a salt marsh: movement between soil, vegetation, and sheep. Bulletin of Environmental Contamination and Toxicology,39: 945952

10. Butkus, D. and Baltrènaitè, E. (2007). Transport of heavy metals from soil to Pinussyl vestris $L$ and Betulapendula trees. Journal of Ecology, 53 (1): 29-36.

11. Chunilall, V., Kindness, A. and Jonnalagadda, S. B. (2005). Heavy metal uptake by two edible Amaranthus herbs grown on soils contaminated with Lead, Mercury, Cadmium and Nickel. Journal of Environmental Science and Health, 40: 375-384.

12. Conti, M. E., Pino, B., and Boca, A. (2008). Lichen Usneabarbata as a biomonitor of airborne element deposition in the Province of Tierra del Fuego (southern Patagonia, Argentina)-Ecotoxicology and Environmental Safety, 72: 1082-1089.

13. Dalton, A. J. and Malanoski, J. (1969). Atomic Absorption Analysis of Copper and Lead in Meat and Meat Products, 52 pp 1035. 
14. Demirezen, O. and Uruc, K. (2006). Comparative study of trace elements in certain fish, meat and meat products. Food Chemistry, 32: 215-222.

15. Elloumi, N., Mezghani, I., Ben Abdallah, F., Chaieb, M. andBoukhris, M. (2005). Fluoride accumulation by vegetation in the vicinity of a phosphate fertilizer plant in Tunisia. Fluoride, 38 (1):18-24.

16. FAO/WHO (2011). Summary report of the seventythird meeting of JECFA. Joint FAO/WHO Expert Committee on Food Additives. Geneva.

17. Geeson, N. A., Abrahams, P. W., Murphy, M. P., and Thornton, I. (1997). Fluorine and metal enrichment of soils and pasture herbage in the old mining areas of Derbyshire, U.K. Agriculture, Ecosystems and Environment,68: 217-231.

18. Holding, B. V. (2004). Water treatment and air purification. Lenntech. Rotterdam sewe. The Netherlands. Pp $58-78$.

19. Jozef, B., B. Pavol, H. Miroslav and Biresova, M. (1997). Distribution of risk elements in the organism of sheep after industrial intoxification with zinc. Spectrosc. Left., 30: 1263-1277.

20. Kabata-pendias, A. and Pendias, H. (1999). Biochemistry of trace elements, Ed. PWN, Warsaw, Pp 240.

21. Kierdorf, H. and Kierdorf, U. (1997). Disturbances of the secretory stage of amelogenesis in fluorosed deer teeth: a scanning electron-microscopic study. Cell Tissue Research, 289: 125-135.

22. McBride M. B. (1998). Growing food crops on sludgeamended soils: problems with the U.S. Environmental Protection Agency method of estimating toxic metal transfer. Environmental Toxicological Chemistry 17 (11): 2274-2281.

23. McLaughlin, M. J., Parker, D. R. and Clarke, J. M. (1999). Metals and micronutrients - food safety issues. Field Crops Research, 60 (1-2): 143-163.

24. Nemade, P. N. and Shrivastava, V. S. (1996). Radiological skeletal changes due to chronic fluoride intoxication in Udaipur (dt). Journal for Environmental Protection, 12 (16): 43- 46.

25. Nguta, C. M., Osawa, W. O., Onyari J. M. and Onyiego, K. B. (2010). Levels of Selected Heavy Metals and Fluoride in Water around Fluorspar Factory in Kerio Valley: Kenya. Kenya Journal Science of Technology and Innovation, 1:12-21.

26. Nouri, J., Khorasani, E. N., Lorestani, E. B., Karami, E. M., Hassani, A. H. \& Yousefi, E. N. (2009). Accumulation of heavy metals in soil and uptake by plant species with phytoremediation potential. Environmental Earth Science, 59:315-323.

27. Oluyemi, E. A., Feuyit, G. J., Oyekunle, J. A. and Ogunfowokan, A. O. (2008). International Journal of Environmental Science and Technology,5 (2): 89 - 96.

28. Opaluwa, O. D., Aremu, M. O., Ogbo, L. O, Abiola, K. A., Odiba, I. E., Abubakar, M. M. and Nweze, N. O.
(2012). Heavy metal concentrations in soils, plant leaves and crops grown around dump sites in Lafia Metropolis, Nasarawa State, Nigeria. Advances in Applied Science Research,3 (2):780-784.

29. Orata, F. (2003). Determination of Heavy Metals in Sediments, Aquatic plants and Fish species from Lake Victoria. Msc thesis, University of Nairobi. Pp 25-66.

30. Osawa, W. O (2009). Levels of fluoride ion and selected heavy metals and their impact on river Kimwarer environment in Kerio Valley- Kenya: MSc thesis Egerton university pp (4, 35-42).

31. Oskarson, A. L., Jorham, L., Sindberg, J., Nilson, N. \& Abanus, L. (1992). Lead poisoning in cattle- Transfer of Lead to milk. Science of the Total Environment, 111: 83-94.

32. Radostits, O. M., Gay, C. C., Hinchcliff, K. W., Constable, P. D. (Ed). (2010). Veterinary Medicine: A Textbook of Disease of Cattle, Sheep, Pig, Goat and Horses London: W. B. Sanders Harcourt Publishers Ltd; p.1815-1819.

33. Roga-Franc, M., Kosla, T. and Rokicki, E. (1996). Cadmium concentration in organs of dairy cows depending on that element contents in meadow cover. Mengen-Spurenelem., Arbeistag., pp: 393-397

34. Sands, M., Nicol, S. and McMinn, A. (1998). Fluoride in Antarctic marine crustaceans. Marine Biology, 132: 591-598.

35. Sami, K. andDruzykli, A. L. (2003). Predicated spatial distribution of naturally occurring arsenic, selenium and uranium in groundwater in groundwater in South Africa Reconnaissance survey (Report No 1236/1/03). Pretoria: Water Research Commission.

36. Shore, R. F. (1995). Predicting cadmium, lead and fluoride levels in small mammals from soil residues and by species-species extrapolation. Journal of Environmental Pollution, 88 (3): 333-340.

37. Tsvetkova, E., Bezlova, D., Karatoteva, L., Malinova and Kolev, G. (2012). Assessment of heavy metals and arsenic content in grasslands of Bulgarka Nature Park. Genetics and Plant Physiology, 2 (3-4): 161170.

38. Turkdogan, M. K., Kulicel, F., Kara, K., Tuncer, I. and Uyang, I. (2003). Heavy metals in soils, vegetable and fruit in the endermic upper gastro intestinal cancer region of Turkey. Environmental, Toxicology and Pharmacology, 13 (3): 175-179.

39. Vasiliki-Anastasia Anagnostau. (2008). Assessment of heavy metals in central Athens and suburbs using plant material p 30-35.

40. WHO (1994). Fluorides and oral health. Report of a WHO Expert Committee on Oral Health Status and Fluoride Use. Geneva, World Health Organization (WHO Technical Report Series 846). 